$\left(\mathrm{CD} 19^{+} \mathrm{CD} 20^{+} \mathrm{IgD}^{-} \mathrm{CD} 27^{-}\right)$declined significantly first at month 6 $(\mathrm{p}=0.033)$ and pre-switching B cells $\left(\mathrm{CD} 19^{+} \mathrm{CD} 20^{+} \mathrm{IgD}{ }^{+} \mathrm{CD} 27^{+}\right)$ showed a trend towards a decrease $(\mathrm{p}=0.052)$. Plasma cells $\left(\mathrm{CD} 138^{+} \mathrm{CD} 38^{+} \mathrm{CD} 27^{+} \mathrm{CD} 19^{+} \mathrm{CD} 3 \mathrm{e}^{-\mathrm{CD}} 20^{-}\right)$and switched memory $\mathrm{B}$ cells $\left(\mathrm{CD} 19^{+} \mathrm{CD} 20^{+} \mathrm{CD} 27^{+} \mathrm{IgD}^{-}\right)$remained stable during the study period, as did $\mathrm{T}$ cells and monocytes $(\mathrm{p}>0.2)$. Despite continuously decreasing SLE Disease Activity Index, immunological changes correlated with clinical improvements only during early time points (month $0-3$ ). Interestingly, high baseline B cell counts were predictive of non-attaining Lupus Low Disease Activity State at month 24 (area under the ROC-curve: 0.95).

Conclusions B cell alterations betided in two distinct phases, a rapid early and a gradual late phase. Late clinical improvements might reflect preceding immunological changes, implying that early treatment evaluation and discontinuation might underestimate delayed improvements reflecting the late B cell changes.

\section{TOLL-LIKE RECEPTOR 7-, BUT NOT TOLL-LIKE RECEPTOR 9-, MEDIATED INTERFERON-A PRODUCTION FROM PLASMACYTOID DENDRITIC CELLS IN PATIENTS WITH SYSTEMIC LUPUS ERYTHEMATOSUS}

K Sakata*, S Nakayamada, Y Miyazaki, S Kubo, K Nakano, Y Tanaka. University of Occupational and Environmental Health, The First Department of Internal Medicine, Kitakyushu, Japan

\subsection{6/lupus-2017-000215.105}

Background and aims Aberrant and persistent production of type I interferon (IFN) is known to play a pivotal role in the pathogenesis of systemic lupus erythematosus (SLE), and plasmacytoid dendritic cells ( $\mathrm{pDCs}$ ) are the major source of type I IFN upon toll-like receptor 7 (TLR7) and TLR9 stimulation. However the respective impacts of TLR7 and TLR9 responses on type I IFN production in SLE has not been addressed.To investigate the precise function of pDCs in SLE patients, we shed light upon the differential regulation of TLR7/9 responses during type I IFN production from pDCs.

Methods PBMCs from SLE patients and healthy controls were analysed in the presence of a TLR7 agonist loxoribine and a TLR9 agonist CpG2216. The IFN- $\alpha$ production in Lin-HLADR+CD123+CD11c- pDCs was detected by flow cytometry.
Results We demonstrated that TLR7-mediated IFN- $\alpha$ production were up-regulated and were positively correlated with disease activity, conversely, TLR9-mediated IFN- $\alpha$ production were down-regulated in SLE. The differential regulation of TLR7/9 responses of pDCs was not dependent on expression levels of TLR7/9. Furthermore, in vitro experiments revealed that up-regulation of TLR7 response was caused by pre-treatment with type I IFNs, conversely, down-regulation of TLR9 response was caused by pre-treatment with type II IFN.

Conclusions This is the first report demonstrated the differential regulation of TLR7- and TLR9- mediated IFN- $\alpha$ production from pDCs in SLE, namely, caused by priming effects of type I and type II IFNs. Taken together, TLR7-, but not TLR9-, mediated IFN- $\alpha$ production contributes the pathogenesis of SLE, and TLR7 could be a potential therapeutic target for SLE.

\section{6 EFFECTS OF BELIMUMAB ON CORTICOSTEROID USE IN
A PIVOTAL PHASE III, RANDOMISED, PLACEBO
CONTROLLED STUDY IN SUBJECTS WITH SYSTEMIC
LUPUS ERYTHEMATOSUS IN NORTH EAST ASIA}

${ }^{1} \mathrm{Y}$ Tanaka* ${ }^{2} \mathrm{D}$ Bass, ${ }^{2} \mathrm{M}$ Chu, ${ }^{3} \mathrm{~S}$ Egginton, ${ }^{3} \mathrm{~B} \mathrm{Ji},{ }^{4} \mathrm{~B}$ Pobiner, ${ }^{2} \mathrm{D}$ Roth, ${ }^{5} \mathrm{YW}$ Song, ${ }^{4} \mathrm{~A}$ Thompson, ${ }^{6} \mathrm{~F}$ Zhang. ${ }^{1}$ University of Occupational and Environmental Health, The First Department of Internal Medicine- School of Medicine, Kitakyushu, Japan; ${ }^{2}$ GSK, Collegeville, Pennsylvania, USA; ${ }^{3}$ GSK, Stockley Park, Uxbridge, UK; ${ }^{4}$ GSK, Raleigh Durham, North Carolina, USA; ${ }^{5}$ Seoul National University Hospital, Seoul, Seoul, Republic of Korea; ${ }^{6}$ Peking Union Medical College Hospital, Chinese Academy of Medical Sciences and Peking Union Medical College, Beijing, China

\subsection{6/lupus-2017-000215.106}

Background and aims Steroid reduction is an important treatment goal in systemic lupus erythematosus (SLE). The steroidsparing effects of belimumab were investigated in subjects in North East Asia.

Methods This multicentre, 52 week study (1 13 750/ NCT01345253) randomised (2:1) subjects ( $\geq 18$ years) with SELENA-SLEDAI ${ }^{38}$ to intravenous belimumab $10 \mathrm{mg} / \mathrm{kg}$ or placebo every 28 days, plus standard SLE therapy. Multiple measures of steroid use (prednisone equivalent) were made, including a secondary endpoint of reduction in dose over 52 weeks among subjects receiving $>7.5 \mathrm{mg} /$ day at baseline

Abstract 106 Table 1 Prednisone dose over 52 weeks

\begin{tabular}{|c|c|c|}
\hline All subjects $(\mathrm{N}=677)$ & Placebo $(n=226)$ & Belimumab $10 \mathrm{mg} / \mathrm{kg}(\mathrm{n}=451)$ \\
\hline $\begin{array}{l}\text { Baseline prednisone dose (all subjects), } \\
\text { mean (SD), mg/day }\end{array}$ & $\begin{array}{l}17.2 \\
(10.82)\end{array}$ & $\begin{array}{l}16.0 \\
(10.66)\end{array}$ \\
\hline $\begin{array}{l}\text { Cumulative prednisone dose over } 52 \text { weeks } \\
\text { (all subjects), median }\left(25^{\circ}, 75^{\infty} \text { percentile), mg* }\right.\end{array}$ & $\begin{array}{c}4758.1 \\
(3597.5,6695.0)\end{array}$ & $\begin{array}{c}4190.0 \\
(3090.0,5475.0)\end{array}$ \\
\hline p-value ${ }^{b}$ & \multicolumn{2}{|c|}{0.0005} \\
\hline $\begin{array}{l}\text { Number of subjects with baseline prednisone dose } \\
>7.5 \mathrm{mg} / \mathrm{day}, \mathrm{n}(\%)\end{array}$ & $\begin{array}{c}184 \\
(81.4)\end{array}$ & $\begin{array}{c}352 \\
(78.0)\end{array}$ \\
\hline $\begin{array}{l}\text { Number of days that prednisone was reduced to } \\
\leq 7.5 \mathrm{mg} / \text { day and/or by } 50 \% \text { from baseline over } \\
52 \text { weeks, median (25 } 25^{\star}, 75^{\star} \text { percentile) }\end{array}$ & $\begin{array}{c}0 \\
(0,172.0)\end{array}$ & $\begin{array}{c}0 \\
(0,213.5)\end{array}$ \\
\hline p-value ${ }^{b}$ & \multicolumn{2}{|c|}{0.0288} \\
\hline $\begin{array}{l}\text { Prednisone reduction by } \geq 25 \% \text { from baseline to } \\
\leq 7.5 \mathrm{mg} / \text { day during Weeks } 40-52, \mathrm{n}(\%)^{c}\end{array}$ & $\begin{array}{c}20 \\
(10.9)\end{array}$ & $\begin{array}{c}55 \\
(15.6)\end{array}$ \\
\hline$p$-value d & \multicolumn{2}{|c|}{0.0721} \\
\hline
\end{tabular}

-Daily dose imputed after dropout/treatment failure; "rank ANCOVA;

among subjects with prednisone dose $>7.5 \mathrm{mg} /$ day at baseline; 'logistic regression;

ANCOVA, analysis of covariance; SD, standard deviation. 


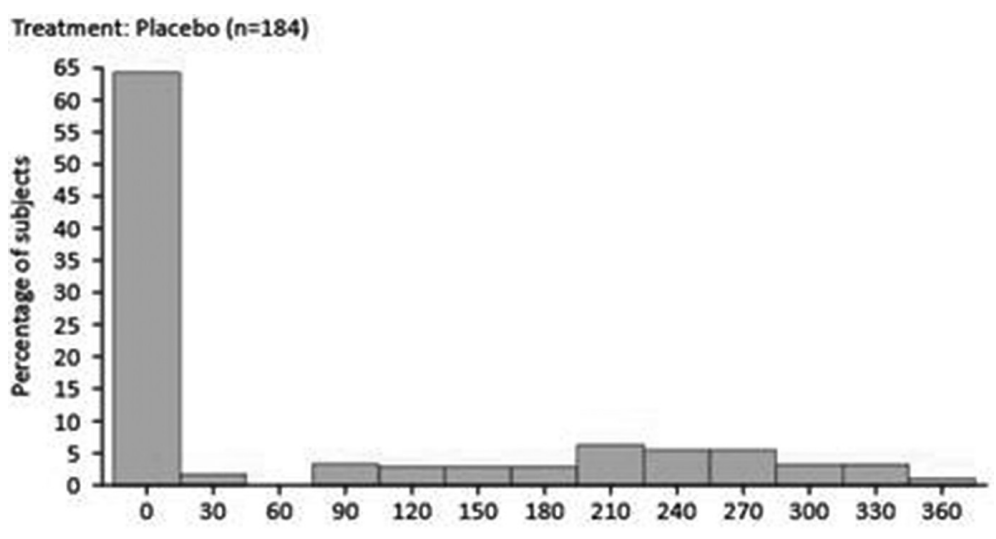

Number of days prednisone dose $\leq 7.5 \mathrm{mg} / \mathrm{day}$ and/or reduced by $50 \%$ over baseline

Treatment: Belimumab $10 \mathrm{mg} / \mathrm{kg}(\mathrm{n}=352)$

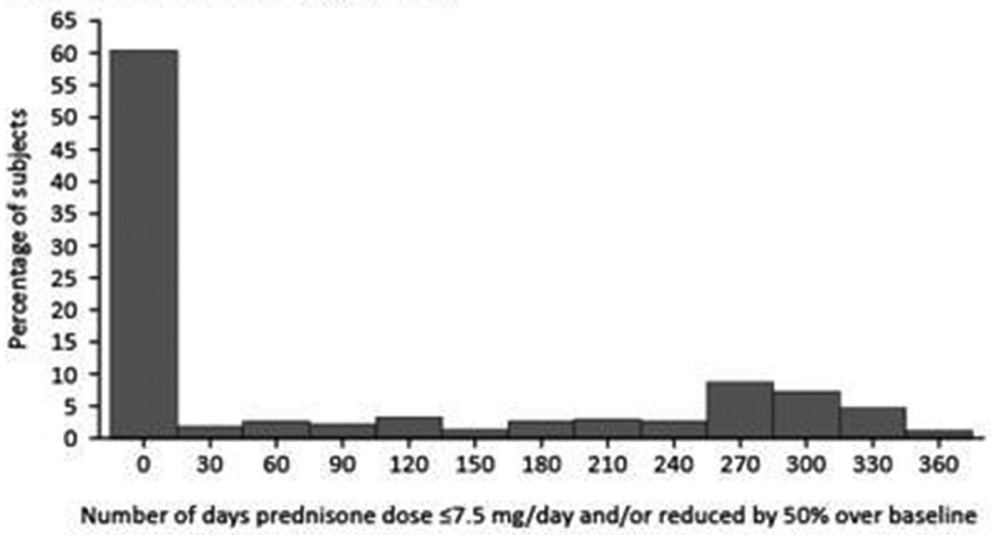

Abstract 106 Figure 1

(number of days $\leq 7.5 \mathrm{mg} / \mathrm{day}$ and/or dose reduced by $50 \%$ from baseline). The primary endpoint was SLE Responder Index response rate at Week 52 (reported elsewhere).

Results Baseline prednisone doses were similar between groups (Table 1). Across the population, cumulative prednisone dose over 52 weeks was significantly lower in the belimumab group versus placebo $(p=0.0005$; Table 1 . For subjects with baseline dose $>7.5 \mathrm{mg} / \mathrm{day}$, the median number of days that prednisone dose was $\leq 7.5 \mathrm{mg} /$ day and/or reduced by $50 \%$ was zero in both groups; however, the $75^{\text {th }}$ percentile was larger for belimumab (213.5 days) versus placebo (172.0), reflecting the subjects who achieved longer durations of reduced steroid use within the belimumab group ( $p=0.0288$; Figure 1$)$. More subjects in the belimumab group had a dose reduction of $\geq 25 \%$ to $\leq 7.5 \mathrm{mg} /$ day during Weeks 40-52 (belimumab, 15.6\%; placebo, 10.9\%: $\mathrm{p}=0.0721$ ). Adverse event incidences were similar (belimumab, 75.7\%; placebo, 74.9\%).

Conclusions These results suggest belimumab is more effective than placebo in reducing steroid use across 52 weeks in this population.

Study funded by GSK.

\section{7 \\ TARGETING SAHH AS A POTENTIAL THERAPEUTIC STRATEGY FOR AUTOIMMUNE DISEASES}

W Tang, Z Jianping*. Shanghai Institute of Materia Medica- Chinese Academy of Sciences, Immunopharmacology, Shanghai, China

\subsection{6/lupus-2017-000215.107}

Background and aims S-Adenosyl-1-homocysteine hydrolase $(\mathrm{SAHH})$ is a highly conserved ubiquitous enzyme that catalyses the hydrolysis of S-adenosyl-1-homocysteine (SAH) to adenosine (Ado) and homocysteine (Hcy) in eukaryotic cells. The reversible type III SAHH inhibitor DZ2002 has been found to have an immunomodulatory function and to alleviate disease in several inflammatory and autoimmune animal models, with greatly reduced cytotoxicity. This study was aim to examine the therapeutic effects and underlying mechanisms of DZ2002 on lupus-prone female NZB/W F1 mice.

Methods NZB/W F1 mice were treated orally with DZ2002 $(0.5 \mathrm{mg} \mathrm{kg}-1)$ for 11 weeks, and the proteinuria level and body weight were monitored. After the mice ware euthanized, serum biochemical parameters and renal damage were determined. Splenocytes of NZB/W F1 mice were isolated for ex 